\title{
PENGARUH FAKTOR GEOGRAFI TERHADAP KEPUTUSAN BERKUNJUNG KE KOTA BANDUNG
}

\author{
Krimayanti ${ }^{1}$ \\ Universitas Pendidikan Indonesia \\ krisma.cima@gmail.com \\ Enok Maryani ${ }^{2}$ \\ Universitas Pendidikan Indonesia \\ enokmaryani@upi.edu \\ Lili Somantri ${ }^{3}$ \\ Universitas Pendidikan Indonesia \\ 1.somantri@ymail.com
}

\begin{abstract}
ABSTRAK
Kota Bandung sebagai destinasi wisata sudah dikenal sejak dulu. Sekarang ini jumlah wisatawan [un terus meningkat. Tujuan penelitian ini untuk mengetahui faktor geografis apayang mempengaruhi keputusan berkunjung ke Kota Bandung. penelitiandilakukan dengan pendekatan kuantitatif melalui metode survey. Populasi adalah wisatawan yang datang ke Kota Bandung.Sampel yang diambil melalui accidental sampling ber 150 orang yang tersebar di 10 objek wisata.Data diambil melalui kuesioner dan diolah melalui regresi.Hasil penelitian menunjukkan wisatawan yang datang didominasi oleh wisatawan produktif, pendidikan SMA, pekerjaan beragam (swasta, negeri, belum bekerja/pelajar), penghasilan menengah ke atas, dan tujuan berkunjung untuk rekreasi menikmati berbagai keramaian kota, kuliner dan belanja. Wisatawan umumnya memiliki loyalitas yang tinggi sebagai pengunjung ( $>4$ kali).Faktor geografi berpengaruh terhadap keputusan berkunjung, berdasarkan urutan kontribusi maka diferensiasi area, nilai kegunaan, aksesibilitas dan lokasi secara berturut-turut memberikan kontribusi tertinggi sampai terkecil.Faktor lokasi yang berupa kemacetan lalu lintas, keberadaan tempat parkir, keamanan di area parkir menjadi faktor yang mempengaruhi tingkat kepuasan wisatawan di objek wisata.Penataan ruang di kawasan objek wisata dan transportasi perlu dilakukan agar tidak banyak waktu wisatawan terbuang akibat kemacetan lalu lintas dan pencarian tempat parkir.
\end{abstract}

Kata kunci: Faktor Geografi, Keputusan Berkunjung. 


\title{
THE INFLUENCE OF GEOGRAPHICAL FACTORS TO THE TOURISTS' VISITATION TO BANDUNG
}

\begin{abstract}
Bandung is a famous tourism destination. It can attract large number of tourists from many cities. As a result, the number of tourists coming to Bandung continually increase. This study aims to investigate geographical factors that can influence tourists' decision to come to Bandung. This study used quantitative method with survey as a design. The populations were the tourists coming to Bandung. The sample was taken by using accidental sampling. There were 150 respondents from 10 tourism objects chosen as the sample. Regarding the data collection technique, questionnaire was used. It was analyzed by using regression. The finding showed that most of tourists coming to Bandung were categorized as productive tourists. Their educational background was high school. Their jobs were varied. Then, they have good income. Concerning their purpose to come, most of them wanted to enjoy Bandung's city and culinary. They also wanted to shop. They were considered to have high loyalty as they have been come for almost 4 times to Bandung. Geographical factors, such as area differentiation, useful value, access, and location, gave significant contribution to the tourists' visitation. Location in this case became the less influential factors. Spatial as well as transportation arrangement was needed to be done in order to maximize tourists' time in tourism object by which they did not spent much time to find park area or stuck in the traffic.
\end{abstract}

Keywords: geographical factor, visitation decision, Bandung

\section{PENDAHULUAN}

Pariwisata merupakan salah satu sektor yang paling diandalkan dalam pembangunan nasional. Perkembangan pariwisata mempengaruhi pembangunan nasional khususnya mendukung perekonomian negara. Pariwisata sangat berpengaruh terhadap beberapa bidang yang mendukung perekonomian yaitu termasuk semakin berkembangnya bidang perhubungan, bidang kerajinan, dan bidang industri kreatif. Pitana dan Gayatri (2005:40) menyatakan bahwa "pariwisata telah menjadi salah satu industri andalan utama dalam menghasilkan devisa negara".

Pengembangan pariwisata sangat tergantung berbagai faktor diantaranya adalah daya tarik wisata. Daya tarik wisata dapat berupa alam, sosial dan budaya yang melekati di masyarakat, dan berbagai hasil ciptaan manusia yang memang sengaja diciptakan untuk 
menarik wisatawan (Maryani, 2005:5) Semakin besar sumber daya wisata tersedia di suatu wilayah semakin besar pula daya tarik wisatanya.

Jawa Barat merupakan provinsi yang memiliki potensi besar dalam sektor pariwisata. Potensi ini dapat dilihat dari keragaman daya tarik wisata seperti keindahan alam, keanekaragaman hayati, keunikan dan kekhasan budaya, serta beragamnya situs peninggalan sejarah. Setiap objek wisata dapat menarik wisatawan untuk berkunjung sehingga dapat menciptakan berbagai kegiatan yang terkait dengan bidang kepariwisataan.

Salah satu destinasi di Jawa Barat yang mengalami perkembangan pesat dalam bidang pariwisata adalah Kota Bandung. Menurut RIPPDA Kota Bandung (2006) faktor yang mendorong Kota Bandung menjadi tujuan pariwisata adalah posisi Kota Bandung sebagai pusat pemerintahan,pusat perekonomian, pusat perdagangan dan industri di Jawa Barat sehingga menjadikan Kota Bandung sebagai pusat kegiatan jasa dan kegiatan perekonomian Jawa Barat. Sejak dibukanya Tol Cipularang, jumlah wisatawan ke Bandung meningkat sekitar 4,8 \% kenaikan pertahunnya (Dinas Pemuda Olahraga Kebudayaan dan Pariwisata Kota Bandung, 2014).

Berdasakan kondisi tersebut di atas, maka penelitian ini bertujuan untuk mengetahui "faktor geografis apa yang berpengaruh terhadap keputusan berkunjung ke Kota Bandung".

\section{METODOLOGI}

Pendekatan yang dipergunaan adalah penelitian kuantitatif, dengan metode survey. Sample penelitian diambil melalui accidental sampling berjumlah 150 di 10 objek wisata yang ada di Kota Bandung yaitu Trans Studio Bandung, Saung Angklung Mang Udjo, Ciwalk XXI, Pasar Baru Trade Center, Paris Van Java, Gedung Sate Bandung, Museum Geologi, Mesjid Agung Bandung, Curug Dago, dan Taman Ir. H. Djuanda. Data diambil melalui kuesioner dan diolah serta dianalisis melalui regresi.Variabel Terpengaruh (Y) adalah Keputusan berkunjung, dan variabel Bebas (X) adalah faktor geografi yang terdiri atas lokasi, aksesibilitas, diferensiasi wilayah dan nilai kegunaan.

Tabel 1.

Variabel Independen

\begin{tabular}{|l|c|l|}
\hline Variabel & Sub Variabel & \multicolumn{1}{c|}{ Indikator } \\
\hline Pengaruh & Lokasi $(\mathrm{X} 1)$ & Informasi yang jelas menuju lokasi. \\
Faktor & & \\
Geografi & & \\
$(\mathrm{X})$ & & \\
& & Sarana tempat parkir yang aman dan luas. \\
\cline { 3 - 3 } & & Kebersihan dan kenyamanan lingkungan. \\
\cline { 3 - 3 } & & Jarak dari tempat asal menuju objek wisata \\
\hline
\end{tabular}




\begin{tabular}{|c|c|}
\hline \multirow{10}{*}{$\begin{array}{l}\text { Aksebilitas } \\
\text { (X2) }\end{array}$} & Kemudahan mencapai objek wisata \\
\hline & Cara mencapai objek wisata \\
\hline & Jenis Transportasi umum \\
\hline & Ketersediaan transportasi umum menuju obyek wisata. \\
\hline & Tarif angkutan menuju obyek wisata \\
\hline & Kondisi jalan \\
\hline & Waktu tempuh \\
\hline & Kesulitan mencapai objek wisata \\
\hline & Keamanan perjalanan \\
\hline & Ketertiban lalu lintas \\
\hline \multirow{5}{*}{$\begin{array}{l}\text { Diferensiasi } \\
\text { Area (X3) }\end{array}$} & Jenis objek wisata \\
\hline & Atraksi objek wisata \\
\hline & Kualitas pelayanan \\
\hline & Mutu kesesuaian \\
\hline & Ciri khas \\
\hline \multirow{4}{*}{$\begin{array}{l}\text { Nilai kegunaan } \\
\text { (X4) }\end{array}$} & Keunikan objek wisata \\
\hline & Aktivitas yang dilakukan \\
\hline & Ketersediaan fasilitas belanja \\
\hline & Ketersediaan tempat tinggal sementara \\
\hline
\end{tabular}

\section{HASIL PENELITIAN DAN PEMBAHASAN}

\section{Kondisi Daerah Penelitian}

Kota Bandung menjadi Ibu Kota Provinsi Daerah Tingkat 1 Jawa Barat, terletak diantara $107^{\circ}$ bujur timur dan $6^{\circ} 55^{\prime}$ Lintang Selatan.Lokasi Kota Bandung sangat strategis terletak pada pertemuan poros jalan barat timur, utara -selatan.Overland destinasi antara Jakarta-Bandung dan Yogyakarta. Sebagai kawasan Inti Bandung Raya Kota Bnadung dikelilingi oleh daerah hinterland yang produktif dengan jumlah penduduk yang banyak seperti Cimahi, Kabupaten Bandung Barat, Kabupaten Bandung, Garut, Cianjur, dan Sumedang. Kota Bandung pun kerap kali menjadi destinasi wisata kuliner bagi orang Jakarta.

Kota Bandung memiliki luas wilayah sebesar $167,31 \mathrm{Km}^{2}$, terdiri atas 30 Kecamatan dan 151 Kelurahan.Iklimnya yang sejuk dan lembab, akibat dilingkupi pegunungan, sangat ideal untuk menjadi tempat rekreasi. Curah hujan rata - rata 204,11 $\mathrm{mm}$ dan jumlah hari hujan rata - rata 18 hari per bulan (Bandung Dalam Angka 2017). Kondisi iklim tersebut, membuat Bandung popular sebagai destinasi wisata sejak jaman Belanda. 
Lahan yang subur dengan morfologi yang menaik di kawasan Bandung Utara menghasilkan keragaman tanaman yang tinggi. Taman-taman Kota Bandung yang ditata ala tropis, ikut mempersejuk iklim dan memperindah kota Bandung sehingga dikenal sebagai Parij van Java. Kota Bandung dilewati oleh 15 sungai sepanjang 265,05 km,salah satunya adalah Sungai Cikapundung yang telah membelah Kota Bandung antara barat dan timur. salah satu bagiannya di kawasan babakan Siliwangi menjadi objek wisata air.

Penduduk Kota Bandung dihuni oleh etnis Sunda dengan berbagai potensi wisata budayanya.Keramahtamahan, keaslian mojang Priangan dan keseniannya telah ikut mempercantik Kota Bandung sebagai destinasi budaya.

\section{Karakteristik Wisatawan}

Karakteristik wistaawan dijabarkan dalam 14 indikator yaitu usia, jenis kelamin, daerah asal, tingkat pendidikan, pekerjaan, pendapatan, biaya yang dikeluarkan, transportasi yang digunakan, tujuan berwisata, teman berwisata, waktu berkunjung, frekuensi berkunjung, lama berkunjung, dan sumber informasi.

Wisatawan yang megunjungi objek wisata di Kota Bandung sebagian besar didominasi oleh wisatawan dewasa.Berdasarkan daya jangkau pasar, wisatawan yang datang mewakili daerah yang ada di Indonesia mulai dari Sumatera, Kalimantan, Sulawesi dan berbagai wilayah di Pulau Jawa.Berdasarkan tingkat pendidikan didominasi oleh wisatawan dengan tingkat pendidikan SMA, wisatawan yang bekerja sebagai karyawan swasta juga dominan dengan berpenghasilan lebih dari Rp. 3.500.000/bulan. Dalam menikmati Bandung wisatawan yang berkunjung ke Kota Bandung umumnya mempergunakan kendaraan umum dan pribadi, dengan tujuan rekreasi mengisi waktu libur.Frekuensi berkunjung umumnya bukan yang pertama kali ( $>4$ kali), dengan ratarata kunjungan 4 jam. Pengetahuan dan daya dorong untuk ke kota Bandung adalah dari keingintahuan, keluarga dan teman. Temuan penilitian ini sejalan dengan temuan Maryani (2017) dan Yudhistira (2016) kebutuhan berwisata muncul disaat tingkat produktivitas meningkat, kelelahan dan kejenuhan dalam bekerja, tingkat ekonomi yang membaik mendorong adanya kebutuhan untuk berwisata.

\section{Faktor Geografi}

Faktor geografi dalam penelitian ini terdiri atas faktor lokasi, aksebilitas, diferensiasi area, dan nilai kegunaan.

1) Faktor Lokasi

Faktor lokasi adalah pengetahuan tentang lokasi Kota Bandung, kejelasan informasi menuju lokasi, kondisi tempat parkir, keamanan tempat parkir, kondisi kebersihan dan kenyamanan lingkungan objek wisata.Secara keseluruhan persentasi faktor lokasi cukup besar yaitu $(71,37 \%)$. Kejelasan informasi menuju lokasi merupakan hal yang paling besar nilainya. Ini menunjukkan rambu-rambu menuju objek, informasi kemenarikan objek, menjadi faktor yang memberi kemudahan bagi wisatawan kalau berkunjung 
ke objek wisata yang ada di Kota Bandung. Pengetahuan tentang lokasi objek wisata tersebut ternyata tidak diimbagi dengan kemudahan dalam memperoleh tempat parkir baik secara luasan maupun informasi tentang ruang-ruang kosong untuk parkir $(68,8 \%)$, sehingga kenyamanan menemukan tempat parkir menjadi terganggu $(67,87 \%)$. Keamanan memarkir kendaraan pun menjadi bagian ketidakpuasan wisatawan $(65,73 \%)$. Sementara itu kebersihan harus menjadi perhatian utama mngingat perolehan nilainya kurang maksimal (73,87\%). Kebersihan, keamanan dan kenyamanan di kawasan objek wisata merupakan hal yang mutlak harus dipenuhi oleh pengelola, mengingat kebutuhan tersebut menjadi prasyarat utama dalam berkunjung ke objek wisata.Kalau saja dari awal wisatawan sudah menemukan kesulitan atau kekecewaan dalam berwisata, maka kepuasan dalam menikmati objek menjadi terganggu.Perolehan nilai secara lebih rinci dapat dilihat pada Tabel 2.

Tabel 2

Analisis Hasil Faktor Lokasi

\begin{tabular}{|c|c|c|c|c|c|c|c|c|}
\hline \multirow{2}{*}{ No } & \multirow{2}{*}{ Pertanyaan } & \multicolumn{5}{|c|}{ Skor Jawaban } & \multirow{2}{*}{ Jumlah } & \multirow{2}{*}{$\begin{array}{l}\text { Skor } \\
\text { Total }\end{array}$} \\
\hline & & 5 & 4 & 3 & 2 & 1 & & \\
\hline \multirow{2}{*}{1} & \multirow{2}{*}{$\begin{array}{c}\text { Kejelasan Informasi } \\
\text { menuju Lokasi }\end{array}$} & 47 & 60 & 41 & 2 & 0 & 150 & 602 \\
\hline & & $31 \%$ & $40 \%$ & $27 \%$ & $1.33 \%$ & 0 & $100 \%$ & $80.27 \%$ \\
\hline \multirow{2}{*}{2} & \multirow{2}{*}{ Luas tempat parkir } & 28 & 54 & 36 & 20 & 12 & 150 & 516 \\
\hline & & $19 \%$ & $36 \%$ & $24 \%$ & $13.3 \%$ & $8 \%$ & $100 \%$ & $68.8 \%$ \\
\hline \multirow{2}{*}{3} & \multirow{2}{*}{$\begin{array}{c}\text { Keamanan tempat } \\
\text { parkir }\end{array}$} & 32 & 40 & 34 & 27 & 17 & 150 & 493 \\
\hline & & $21 \%$ & $27 \%$ & $23 \%$ & $18 \%$ & $11 \%$ & $100 \%$ & $65.73 \%$ \\
\hline \multirow{2}{*}{4} & \multirow{2}{*}{ Kondisi kebershan } & 42 & 52 & 30 & 20 & 6 & 150 & 554 \\
\hline & & $28 \%$ & $35 \%$ & $20 \%$ & $13.3 \%$ & $4 \%$ & $100 \%$ & $73.87 \%$ \\
\hline \multirow[b]{2}{*}{5} & \multirow{2}{*}{$\begin{array}{c}\text { Kenyamanan } \\
\text { lingkungan objek } \\
\text { wisata }\end{array}$} & 23 & 50 & 46 & 25 & 6 & 150 & 509 \\
\hline & & $15 \%$ & $33 \%$ & $31 \%$ & $16.7 \%$ & $4 \%$ & $100 \%$ & $67.87 \%$ \\
\hline \multicolumn{8}{|c|}{ Total Skor } & 2674 \\
\hline \multicolumn{8}{|c|}{ Persentase Skor } & $71.37 \%$ \\
\hline
\end{tabular}

Hasil olahan peneliti

2) Faktor Aksebilitas

Aksebilitasmerupakan kemudahan menjangkau objek wisata, termasuk didalamnya keberadaan prasarana dan sarana transportasi, kondisi jalan, kemudahan memperoleh kendaraan umum, waktu tempuh, biaya, keamanan dan kenyamanan dalam berkendaraan. Keberadaan prasarana dan sarana transportasi, kemudahan dalam menemukan kendaraan umum, kemudahan mencapai objek, kondisi jalan, biaya transportasi mendapatkan skor tinggi, walaupun wisatawan ternyata mendapatkan kesulitan untuk mengakses objek wisata pada saat libur, akibat kemacetan lalu lintas sehingga membuat perjalanan menjadi semakin lama. 
Tabel 3

Analisis Faktor Aksebilitas

\begin{tabular}{|c|c|c|c|c|c|c|c|c|}
\hline \multirow{2}{*}{ No } & \multirow{2}{*}{ Pertanyaan } & \multicolumn{5}{|c|}{ Skor Jawaban } & \multirow{2}{*}{ Jumlah } & \multirow{2}{*}{$\begin{array}{l}\text { Skor } \\
\text { Total }\end{array}$} \\
\hline & & 5 & 4 & 3 & 2 & 1 & & \\
\hline \multirow{2}{*}{1} & \multirow{2}{*}{$\begin{array}{c}\text { Kemudahan } \\
\text { mencapai objek } \\
\text { wisata. }\end{array}$} & 64 & 55 & 24 & 7 & 0 & 150 & 626 \\
\hline & & $42.7 \%$ & $37 \%$ & $16 \%$ & $4.7 \%$ & 0 & $100 \%$ & $83.4 \%$ \\
\hline \multirow{2}{*}{2} & \multirow{2}{*}{$\begin{array}{c}\text { Cara mencapai objek } \\
\text { wisata }\end{array}$} & 93 & 44 & 13 & 0 & 0 & 150 & 319 \\
\hline & & $62 \%$ & $29,3 \%$ & $8,6 \%$ & 0 & 0 & $100 \%$ & $42,5 \%$ \\
\hline \multirow{2}{*}{3} & \multirow{2}{*}{$\begin{array}{c}\text { Transportasi umum } \\
\text { yang tersedia }\end{array}$} & 0 & 17 & 0 & 118 & 15 & 150 & 675 \\
\hline & & & $11,3 \%$ & 0 & 78,7 & $10 \%$ & $100 \%$ & $90 \%$ \\
\hline \multirow{2}{*}{4} & \multirow{2}{*}{$\begin{array}{c}\text { Tingkat kemudahan } \\
\text { dalam menemukan } \\
\text { angkutan umum }\end{array}$} & 150 & 0 & 0 & 0 & 0 & 150 & 750 \\
\hline & & $100 \%$ & 0 & 0 & 0 & 0 & $100 \%$ & $100 \%$ \\
\hline \multirow[b]{2}{*}{5} & \multirow{2}{*}{$\begin{array}{l}\text { Biaya yang } \\
\text { dikeluarkan } \\
\text { menggunakan } \\
\text { angkutan umum }\end{array}$} & 45 & 58 & 22 & 19 & 6 & 150 & 567 \\
\hline & & $30 \%$ & $39 \%$ & $15 \%$ & $13 \%$ & $4 \%$ & $100 \%$ & $75.6 \%$ \\
\hline \multirow{2}{*}{6} & \multirow{2}{*}{$\begin{array}{l}\text { Kondisi jalan menuju } \\
\text { objek wisata }\end{array}$} & 39 & 73 & 30 & 6 & 2 & 150 & 591 \\
\hline & & $26 \%$ & $49 \%$ & $20 \%$ & $4 \%$ & $1.3 \%$ & $100 \%$ & $78.8 \%$ \\
\hline \multirow{2}{*}{7} & \multirow{2}{*}{$\begin{array}{l}\text { Lama waktu tempuh } \\
\text { menuju objek wisata }\end{array}$} & 21 & 44 & 62 & 19 & 4 & 150 & 509 \\
\hline & & $14 \%$ & $29 \%$ & $41 \%$ & $13 \%$ & $2.7 \%$ & $100 \%$ & $67.8 \%$ \\
\hline \multirow{2}{*}{8} & \multirow{2}{*}{$\begin{array}{c}\text { Kesulitan menuju } \\
\text { objek wisata }\end{array}$} & 8 & 7 & 133 & 3 & 0 & 151 & 473 \\
\hline & & $5.33 \%$ & $4.7 \%$ & $89 \%$ & $2 \%$ & 0 & $100 \%$ & $63.7 \%$ \\
\hline \multirow{2}{*}{9} & \multirow{2}{*}{$\begin{array}{c}\text { Keamanan menuju } \\
\text { objek wisata }\end{array}$} & 36 & 62 & 45 & 6 & 1 & 150 & 576 \\
\hline & & $24 \%$ & $41 \%$ & $30 \%$ & $4 \%$ & $0.7 \%$ & $100 \%$ & $76.8 \%$ \\
\hline \multirow{2}{*}{10} & \multirow{2}{*}{$\begin{array}{l}\text { Ketertiban lalu lintas } \\
\text { di objek wisata }\end{array}$} & 45 & 75 & 30 & 0 & 0 & 150 & 615 \\
\hline & & $30 \%$ & $50 \%$ & $20 \%$ & 0 & 0 & $100 \%$ & $82 \%$ \\
\hline \multicolumn{8}{|c|}{ Total Skor } & 6075 \\
\hline & & Perse & tasi Sk & & & & & $81 \%$ \\
\hline
\end{tabular}

Sumber:Hasil Olahan Peneliti

Keterbatasan kapasitas dan daya dukung jalan dalam menampung kendaraan yang ada pada musim liburan, membuat jalanan menjadi macet. Hal ini diperparah dengan keterbatasan tempat parkir, sehingga sebagian badan jalan menjadi ruang parkir, mempersempit badan jalan.Kondisi ini membuat ketidakpuasan bagi wisatawan, karena banyak waktu yang terbuang di jalanan, padahal bagi mereka waktu sangat berharga untuk menikmati objek dan tujuan perjalanan adalah untuk refreshing atau re-kreasi.

\section{3) Faktor Diferensiasi Area}

Diferensiasi area merupakan perbedaan antara daerah tujuan dengan daerah asal wisatawan.Wisatawan umumnya ingin menikmati sesuatu yang berbeda dari daerah asalnya.Setiap wilayah memiliki keunikan, kekhasan dan perbedaan dalam bentuk alam maupun aktivitas manusia.Variasi wilayah tersebut dapat mendorong rasa ingin tahu dan keinginan untuk berkunjung. Faktor diferensiasi hanya mencapai skor 1713 dari skor tetinggi 2250, sehingga persentasinya mencapai $76,13 \%$ atau termasuk kedalam kriteria baik. Artiya wisatawan mendapatkan sesuatu yang berbeda di daerah tujuan wisata. 
Tabel 4

Analisis Faktor Diferensiasi Area

\begin{tabular}{|c|c|c|c|c|c|c|c|c|}
\hline \multirow{2}{*}{ No } & \multirow{2}{*}{ Pertanyaan } & \multicolumn{5}{|c|}{ Skor Jawaban } & \multirow{2}{*}{$\underset{\mathrm{h}}{\text { Jumla }}$} & \multirow{2}{*}{$\begin{array}{l}\text { Skor } \\
\text { Total }\end{array}$} \\
\hline & & 5 & 4 & 3 & 2 & 1 & & \\
\hline \multirow[b]{2}{*}{1} & \multirow{2}{*}{$\begin{array}{c}\text { Kualitas } \\
\text { pelayanan di } \\
\text { objek wisata }\end{array}$} & 34 & 62 & 48 & 5 & 1 & 150 & 573 \\
\hline & & $\begin{array}{r}22.7 \\
\%\end{array}$ & $41 \%$ & $32 \%$ & $3.3 \%$ & $0.7 \%$ & $100 \%$ & $76.4 \%$ \\
\hline & \multirow{2}{*}{$\begin{array}{c}\text { Kesesuaian } \\
\text { Objek Wisata } \\
\text { yang diatawarkan } \\
\text { dengan yang } \\
\text { disediakan }\end{array}$} & 43 & 61 & 43 & 2 & 1 & 150 & 593 \\
\hline 2 & & $\begin{array}{r}28.7 \\
\% \\
\end{array}$ & $41 \%$ & $28.7 \%$ & $\begin{array}{r}1.33 \\
\% \\
\end{array}$ & $0.7 \%$ & $100 \%$ & $79.7 \%$ \\
\hline \multirow[b]{2}{*}{3} & \multirow{2}{*}{$\begin{array}{c}\text { Perbedaan } \\
\text { dengan daerah } \\
\text { asal }\end{array}$} & 33 & 55 & 41 & 18 & 3 & 150 & 547 \\
\hline & & $22 \%$ & $37 \%$ & $27.3 \%$ & $12 \%$ & $2 \%$ & $100 \%$ & $72.9 \%$ \\
\hline \multicolumn{8}{|c|}{ Total skor } & 1713 \\
\hline & & $\mathrm{Pe}$ & entasi & & & & & $76.1 \%$ \\
\hline
\end{tabular}

Sumber: Hasil OlahanPeneliti

Variasi antara daerah asal dengan daerah tujuan secara spesifik medapatkan persentasi yang cukup tinggi $(72,9 \%)$, harapan adanya perbedaan tersebut ternyata mendapatkan kesesuaian antara harapan dengan kenyataan $(79,7 \%)$, demikian pula dengan kualitas pelayanan yang diberikan sudah menunjukkan harapan $(76,4)$ dan dapat memberikan kepuasan secara baik. Kondisi ini menunjukkan diferensiasi wilayah memberikan kepuasan dan sesuai dengan harapan.

\section{4) Faktor Nilai Kegunaan}

Nilai kegunaan berhubungan dengan keberadaan fasilitas yang ada di sekitar objek wisata yang dapat digunakan dan memenuhi kebutuhan wisatawan selama mengadakan perjalanan wisata.Keberadaan fasilitas tersebut, bukan hanya berguna secara fisik dalam memenuhi kebutuhan tapi juga memberikan kepuasan selama mengandakan kunjungan ke objek-objek wisata.faktor nilai kegunaan memperoleh jumlah skor 1675 dengan persentasi $74,44 \%$. Berdasarkan skor yang dicapai tersebut maka nilai kegunaan beserta indikatornya berada pada kriteria baik. Berikut penjelasan mengenai pertanyaan dari faktor nilai kegunaan sebagai berikut :

Tabel 5

Analisis Faktor Nilai Kegunaan

\begin{tabular}{|c|c|c|c|c|c|c|c|c|}
\hline \multirow{2}{*}{ No } & \multirow{2}{*}{ Pertanyaan } & \multicolumn{5}{|c|}{ Skor Jawaban } & \multirow{2}{*}{ Jumlah } & \multirow{2}{*}{$\begin{array}{l}\text { Skor } \\
\text { Total }\end{array}$} \\
\hline & & 5 & 4 & 3 & 2 & 1 & & \\
\hline \multirow[b]{2}{*}{1} & \multirow{2}{*}{$\begin{array}{c}\text { Kelengkapan } \\
\text { fasilitas di objek } \\
\text { wisata }\end{array}$} & 30 & 55 & 36 & 24 & 5 & 150 & 531 \\
\hline & & $20 \%$ & $36.67 \%$ & $24 \%$ & $16 \%$ & $3.33 \%$ & $100 \%$ & $70.8 \%$ \\
\hline \multirow[b]{2}{*}{2} & \multirow{2}{*}{$\begin{array}{l}\text { kelengkapan } \\
\text { fasilitas } \\
\text { berebelanja di } \\
\text { objek wisata }\end{array}$} & 53 & 60 & 32 & 3 & 1 & 149 & 608 \\
\hline & & $35.33 \%$ & 40 & $21.33 \%$ & 2 & $0.67 \%$ & $99.33 \%$ & $81.07 \%$ \\
\hline \multirow{2}{*}{\multicolumn{2}{|c|}{\begin{tabular}{|c|c} 
Tempat tinggal \\
sementara yang \\
tersedia di objek \\
wisata
\end{tabular}}} & 33 & 55 & 37 & 15 & 10 & 150 & 536 \\
\hline & & 22 & $36.67 \%$ & $24.67 \%$ & $10 \%$ & $6.67 \%$ & $100 \%$ & $71.47 \%$ \\
\hline \multicolumn{8}{|c|}{ Total skor } & 1675 \\
\hline \multicolumn{8}{|c|}{ Persentasi Skor } & $74.44 \%$ \\
\hline
\end{tabular}

Sumber: Hasil Olahan Peneliti 


\section{Keputusan Berkunjung}

Keputusan Berkunjung dalam penelitian ini menjadi variabel bebas yang tunggal. Keputusan berkunjung dipengaruhi oleh beberapa faktor antara lain keberagaman objek, keunikan, citra baik dan kualitas pelayanan. Dalam menentukan objek biasanya melalui beberapa tahap yaitu pemilihan objek wisata, pemilihan jenis wisata, pemilihan agen dan perjalanan, Frekuensi kunjungan atau revisit intention dapat menggambarkan kepuasan dan loyalitas terhadap objek wisata di suatu tempat.Penilaian terhadap keputusan berkunjung, berdasarkan akumulasi faktor tersebut di atas menghasilkan nilai relatif 80,33 \%. Wisatawan menilai bahwa objek wisata di Kota Bandung keunikan (97\%), kualitas pelayanan (94\%), citra baik (77\%) dan keberagaman objek (70\%) merupakan faktor yang menentukan keputusan berkunjung

\section{Pengaruh Faktor Geografi terhadap Keputusan Berkunjung di Kota Bandung}

Berdasarkan nilai koefisiensi korelasi pengaruh faktor geografis terhadap keputusan berkunjung menunjukkan nilai yang signifikan $(0,000)$ dengan nilai korelasi sebesar 0,347 atau kontribusinya sebanyak $35 \%$ dalam menentukan keputusan berkunjung.Kempat variable bebas yaitu faktor lokasi, aksesibilitas diferensiasi wlayah, nilai kegunaan menununjukan nilai yang signifikan $(<0.005)$ walaupun kontribusinya terhadap keputusan berkunjung berbeda-beda.Hal ini sejalan dengan pendapat Milinillo dan Japutra(2016, hlm. 7) bahwa faktor lokasi berpengaruh terhadap probalitas wisatawan untuk menghadiri atraksi wisata.Faktor lokasi yang berpengaruh memiliki kemungkinan besar bahwa wisatawan yang mengunjungi atraksi wisata adalah wisatawan domestik.Demkian pula dengan aksesibilitas, Syahrul(2015, hlm.78) menyatakan bahwa aksesibilitas memiliki pengaruh terhadap keputusan wisatawan untuk berkunjung ke suatu kawasan, dengan adanya kemudahan akses informasi dan komunikasi, keamanan dan transportasi yang lancar merupakan faktor penting untuk meningkatkan jumlah kunjungan wisatawan.

Faktor diferensiasi area adalah faktor perwujudan unsur-unsur lingkungan baik yang bersifat alami, budaya atau hasil buatan (artificial). Integrasi suatu fenomena menjadikan sebuah corak tersendiri sebagai suatu region yang berbeda dari suatu tempat atau wilayah yang lain. Pada penelitian difrensiasi area memiliki pengaruh terhadap keputusan berkunjung, hal ini sejalan dengan Pandensolang(2015,hlm.1123) bahwa diferensiasi produk mempengaruhi keputusan pembelian secara signifikan. Faktor nilai kegunaan adalah nilai kegunaan suatu wilayah yang dapat dikembangkan mejadi potensi yang menunjang untuk perkembangan wilayah. Pada penelitian pariwisata Kota Bandung, nilai kegunaan yang berpengaruh terhadap keputusan berkunjung, temuan ini sejalan dengan penelitian yang dilakukan oleh Lapian dkk.(2015,hlm 1087) yaitu nilai guna suatu objek bagi wisatawan berpengaruh terhadap keputusan berkunjung di Pantai Firdahaus Munahasa Utara. 


\section{SIMPULAN}

Bandung sebagai daerah tujuan wisata masih memiliki daya tarik bagi wisatawan mancanegara dan domestic.Keberagaman objek wisata, keunikan, citra baik dan kualitas pelayanan merupakan faktor penting yang mendorong wisatawan datang ke Kota Bnadung. Wisata kota dan wisata alam sekitar Bandung menjadi atraksi utamanya. Wisatawan yang datang didominasi oleh wisatawan produktif, pendidikan SMA, pekerjaan beragam (swasta, negeri, belum bekerja/pelajar), penghasilan menengah ke atas, dan tujuan berkunjung untuk rekreasi menikmati berbagai keramaian kota, kuliner dan belanja. Wisatawan umumnya memiliki loyalitas yang tinggi sebagai pengunjung (> 4 kali). Teman, tetangga, dan keluarga merupakan daya dorong utama yang mebuat wisatawan berkunjung kembali ke Kota Bandung. Faktor geografi yang berupa lokasi, aksesibilitas, diferensiasi area dan nilai kegunaan secara signifikan berpengaruh terhadap keputusan berkunjung.Bila diurutkan berdasarkan kontribusinya maka diferensiasi area, nilai kegunaan, aksesibilitas dan lokasi secara berturut-turut memberikan kontribusi dari yang paling besar sampai yang terkecil. Faktor lokasi yang berupa kemacetan lalu lintas, keberadaan tempat parkir, keamanan di area parkir menjadi factor yang mempengaruhi tingkat kepuasan mereka di objek wisata.

Dari hasil penelitian tersebut, disarankan penataan objek wisata, transportasi di Kota Bandung mulai dari pintu gerbang masuk (gateentry), transportasi di dalam kota, transportasi menuju objek, ketersediaan dan daya dukung areal parkir perlu benahi agar waktu wisatawan menjadi efektif untuk menikmati kemenarikan Kota Bandung.

\section{DAFTAR PUSTAKA}

Badan Pusat Statistik. 2016. Kota Bandung dalam Angka 2012-2016. https://bandungkota.bps.go.id/. (Diakses pada 24April 2017)

Basu Swastha Dharmmesta dan T. Hani Handoko.(2000). Manajemen Pemasaran, Analis a Perilaku Konsumen. Yogyakarta: BPFE-Yogyakarta

Hermansyah dan Waluya B (2012). Analisis faktor - faktor Pendorong Motivasi Wisatawan Nusantara Terhadap Keputusan Berkunjung ke Kebun Raya Bogor. Tourism and Hospitality Essentials (THE) Journal, 2(1).hlm 2012 - 267.

Kementerian Pariwisata. 2015.1. http://www.kemenpar.go.id/asp/detil.asp?c=7\&id=2900. Diakses tanggal 24 April 2017.

Kotler dan Amstrong.(2012). Prinsip - Prinsip Pemasaran. Jakarta : Erlangga

Lapian dkk.(2015). Pengaruh Adversisting dan Daya Tarik Wisata Terhadap Keputusan Mengunjungi Objek Wisata Pantai Firdaus Di Kabupaten Minahasa Utara. Jurnal EMBA. 3(3). Hlm 1079 - 1088.

Maryani. (2005). Struktur Keruangan Pariwisata, Makalah.

Milinillo dan Japutra. (2016). Factors influencing domestic tourist attendance at cultural attractions in Andalusia, Spain. Journal of Destination Marketing \& Management 
Pandensolang, JD dan Tawas, HN.(2015). Pengaruh Diferensiasi, Kualitas Produk, Dan Ekuitas Merek Terhadap Keputusan Pembelian Cola - Cola Pada PT. Bangun Wenang Beverges Company Di Manado.

Pemerintah Kota Bandung. 2006. Rencana Induk Pengembangan Pariwisata. Departemen Kebudayaan dan Pariwisata. https:/www.bandungtourism.com/files/PERDA_01-2013_RIPPDA_1.pdf. Diakses Tanggal 24 April 2017.

Pitana, I Gde.dan Surya Diarta, I Ketut. 2009. Pengantar Ilmu Pariwisata. Yogyakarta : Penerbit Andi.

PPID Kota Bandung. Data Kunjungan Wisatawan Kota Bandung. https://ppid.bandung. go.id/knowledgebase/data-kunjungan-wisatawan-yang-datang-ke-kota-bandungtahun-2010-2015/. Diakses tanggal 24 April2017.

Syahrul, Alfattory Rheza. (2015). "Pengaruh Daya Tarik, Fasilitas Dan Aksebilitas Terhadap Keputusan Wisatawan Asing Berkujung Kembali Ke Aloita Resort Di Kabupaten Kepulauan Mentawai", dalam JurnalResearch of Education and Develpoment.7(1),71 -82.

Yudhhistira, G. \& Octavia, D. (2016).Analisis daya tarik kota bandung sebagai destinasi pariwisata berdasarkan Memorable tourism experience. Telkom University 